\title{
WHAT SKILLS ACCOUNTING STUDENTS NEED: EVIDENCE FROM STUDENTS' PERCEPTIONS AND PROFESSIONALS' EXPECTATIONS
}

\author{
DOI: 10.17261/Pressacademia.2019.1149 \\ JEFA- V.6-ISS.4-2019(1)-p.184-191
}

\section{Feyza Derekoy}

Canakkale Onsekiz Mart University, Canakkale Social Sciences Vocational School, Terzioglu Campus, Canakkale, Turkey. fderekoy@comu.edu.tr, ORCID: 0000-0003-1508-7498.

Derekoy, F., (2019). What skills accounting students need: Evidence from students'perceptions and professionals' expectations. Journal of Economics, Finance and Accounting (JEFA), V.6(4), p.184-191.

Permemant link to this document: http://doi.org/10.17261/Pressacademia.2019.1149

Copyright: Published by PressAcademia and limited licenced re-use rights only.

\section{ABSTRACT}

Purpose- The aim of the study is to identify the skills that should be gained in accounting education according to the perceptions of students and the expectations of professional accountants and to determine whether there is a difference between the opinions of students and professionals.

Methodology- A questionnaire which includes the skills to be gained in accounting education, was applied to the students in different departments where accounting education is given, at Çanakkale Onsekiz Mart University. It was also applied to the accounting professionals registered to Çanakkale Chamber of Certified Public Accountant.

Findings- The results of the study revealed that there were differences between the opinions of students and professional accountants in 11 out of 30 skills that should be included in accounting education.

Conclusion- Although there are similarities between students' perceptions and expectations of professionals, there are some differences. It would be appropriate to review and update the accounting education in line with the expectations considering these differences.

Keywords: Accounting education, accounting skills, accounting curriculum, accounting student, accountancy profession. JEL Codes: M40, M41, M49.

\section{INTRODUCTION}

In the global competition environment, the most important toll of competition is the timely production and use of knowledge. Besides, in the production and use of knowledge, accounting undertakes the most important task. As a component of management information system, accounting which has a higher advantage, should produce information which helps to the organizatons for improving their performance and using this information for continuous improvement of activities.

Accounting is the process of preparing, reporting and interpreting financial information that is provided to decision makers (Ingram and Albright, 2007: 20). Accounting and accountancy profession, plays a leading role in the right and effective decision-making process and the preparation of future plans. The first requirement for the accountant to fulfill this function effectively is the existence of well-educated accountants who know the responsibility of the profession (Özdemir \& Elitaş, 2015). Therefore, the accountant must have the necessary field expertise and the ability to use the necessary equipment in order to use his knowledge in the best way. Accordingly, the first condition for increasing the quality of the accounting profession is to increase the quality of education in the subjects that require knowledge of accounting expertise (Kalmış \& Yılmaz, 2004).

Accounting education is a vocational education and the expected thing from this education is bringing the knowledge and skills required by the profession (Zaif and Ayanoğlu, 2007: 117). Accounting education aims to inform the person receiving accounting training, about determination, collection, processing, checking of accuracy and summarizing of useful information for business and for decision making and to develop abilities of person receiving accounting training, on the implemantation of these information. Therefore, the main purpose of accounting education is give an education in the matter of proving accurate and reliable accounting information to those who are in need of financial information and to direct applications accordingly (Gökçen, 1998: 43- 50).

In recent times, the problems in accounting education are discussed even in literature, conferences, panels and congresses. One of the main problem is insufficiency of accounting education to develop critical thinking, communication and problem 
solving abilities of students (Çürük ve Doğan, 2001: 30). The other main problem is related to accounting courses and contents. The accounting courses fail to educate future accountants adequately to face the rapidly chaning global environment of the future. In addition, the course contents are insufficient to meet the requirements of the profession (Asonitou, 2015).

While the rapid and continous changes take place in business life, a structural changing in accounting education occurs very slowly. So, this causes a gap between accountant education and accounting practices (Kendirli et al., 2015: 55). In other words, accouting programmes are not harmony with the requirements of the real world. Accounting programmes need to develop a group of crucial skills (Tan and Fawzi, 2017). Accounting programmes should contain attributes that prepare future accountants as lifelong leaners, as global citizens (Kavanagh and Drennan, 2008: 280). Future accountants should have ability to use information technology, to work in team, to communicate effectively and also should be equipped with features to evaluate and interpret information, to draw attention to issues and identify and put forth information neccessary for management (Dağdeviren et al., 2016: 493; Sürmeli, 2007: 30).

In this study, it was tried to find out which skills should be gained to students in accounting education from the point of view of both students and professionals. In addition, it was analyzed whether there was a difference between the perceptions of the students and the expectations of the professionals. In this context, firstly the skills covered by the accounting curriculum in the training process will be described. In the literature section of the study, previous studies on the subject will be reviewed and related search questions will be determined. In the final section, a research aiming to reveal the differences in the perspectives of students and professional accountants about the skills required in accounting education will be conducted and research findings will be presented.

\section{SKILLS IN ACCOUNTING EDUCATION}

Accounting programmes need to produce graduates with the skills necessary for their professional careers. Skills are capabilities which include knowledge, professional values, ethics and behaviors to perform accounting tasks required from accounting profession (Chaker and Abdullah, 2011: 194).

At the present time, the obtaining and assessment of data, the organization and protection of files, the interpretation, communication and use of computer processed information, the understanding of social, organizational and technological systems, the observing and correcting performance and planning and improving systems are the skills required in accounting education (Mohammed and Lashine, 2003: 6). There are several classification of these skills in literatures. In this study, the classification of AICPA (The American Institute of Certified Professional Accountants) has been adopted. They are generic, functional and information technology related skills are described as follows;

Generic Skills: Professional accountant should have a series of skills as critical thinking, interpersonal and lifelong learning skills along with professional knowledge (Sin and Reid, 2005: 13). Generic skills include oral and written communication, teamwork, ethical behavior, critical thinking and problem solving. According to some research findings, accounting education programmes fail to provide oral and written communication skills to accountant graduates, although these skills are highly important to employability and enduring success (Kearns, 2014: 27).

Functional Skills: Functioal skills consist of skills specific to acountancy (Awayiga and et al., 2010: 142). Functional skills are the traditional skills relevant to the mastery of accounting knowledge such as budgeting, income tax and preperation and analysis of financial statement and auditing analysis (Kearns, 2014: 27).

Information Technology Related Skills: The accounting education should provide information technology knowledge that accounting students need to use and evaluate information technology and systems and also design and management of those sytems. Every accountant must have the ability to use a word processing package, a spread-sheet package, a database package and at least one entry-level accounting package (Awayiga and et al., 2010: 143). An ideal accounting education includes both conceptual knowledge and application skills in a wide range of information technologies (Greenstein and McKee, 2004: 216). Information technologies should be integrated into the current accounting education programmes. This integration brings about accounting education programmes being more analytical and interdisciplinary as information technology system is used to analyse information and for decision making, not only a technical function. It is also important to identify what skills should be included in an information technology course of accounting education programme in order to remove the gap between academic education and professional requirements (Stumke, 2017: 123-124).

\section{LITERATURE REVIEW AND RESEARCH QUESTIONS}

There are many studies regarding the significance level of skills expected to gain during the accounting education. Klibi and Oussii (2013) determined that technical skills were evaluated as more important skills than other group of skills in accounting education. In this context, students ranked the top three skills as, preparation of financial statements, technical bookkeeping and accounting for depreciation and provision. Jackling and De Lange (2009) investigated the emphasis placed on technical and generic skills gained during the accounting education from both the students and employers perspective. Students perceived that the technical skills were more importance than the generic skills. According to the students, the most significant skills were accounting problem analysis, key accounting skills. Similiarly, Gabric and Mc Fadden (2001) investigated students' and employers' perceptions about accounting skills. According to the search results, students perceived verbal 
communication, problem solving and listening skills as the most important generic skills, also spreadsheet proficiency, operating systems abilities and word processing knowledge were identified as the top three technical skills by students. Hence the first research question was stated as follows;

\section{Q1: What is the significance level of accounting skills perceived by students?}

The skills of accounting graduates highly valued by accounting professionals have also been investigated. Albrecht and Sack (2000) investigated the perceptions of accounting professionals and academicians concerning skill development. Professionals ranked the skills they believed as most important, were written communications, analytical-critical thinking, oral communication and computing technology. Likewise, Uyar and Güngörmüş (2011) tried to determine the accounting skills that were considered important by external auditors for accounting graduates who intend to be auditors. Search results revealed that all skills except accounting software, were perceived as important for auditing profession. The most important skills were valued as ethics, teamwork and honesty. In the study conducted by Arsoy et al.(2014), the opinions of professionals and academicains were compared in terms of knowledge, skills, and training techniques that should be acquired in accounting education. As a result of the study, it was found that academicains and professionals had different opinions about the content and method of accounting education. Paratama (2015) conducted a survey to compare accouting knowledge and skills and analyze gaps between the academicians and professionals views. Research results demostrated that professionals considered financial accounting and reporting was the most important knowledge, while business and trade law was the least important knowledge. Furthermore, academicians and professionals agreed that the ability to investigate and examine, logical thinking, cause-effect analysis and critical analysis and teamwork were important skills. Moreover Hence the second research question is stated as follows;

\section{Q2: What is the significance level of accounting skills perceived by accounting professionals?}

Likewise, some studies in literature have been conducted in order to highlight the different viewpoints of accounting students, professionals. Kavanagh and Drennan (2008) conducted a study in order to examine perceptions and expectations of students and practitioners. The results of the study states that there is a concurrence between students and practitioners in terms of lifelong learning skills such as problem solving skills, oral and written communication skills and continous learning. According to the findings, students focus on ongoing development personal skills while practitioners place emphasis on background knowledge, life experience and work-related skills. Lin, Xiong and Liu (2005) used a survey to analyze the perceived importance of knowledge and skills by students, professionals and academicians for accounting education. The skills of analytical-critical thinking, decision making and written and oral communication which accounting professionals emphasized, were not sufficiently perceived by students. Also, there were large variances between the perceived importance of the knowledge and skills as finance, business law, auditing services, information systems, ethics and social responsibility, global business and E-commerce. Francisco and Kelly (2002) aimed to compare attitudes of skill importance between accounting students, academicians and professionals. The results of the research showed that differences in the views of three groups were unimportant. These three groups recognized many of the same skills as being extremely important. Only, such skills as analytical- critical thinking and computer technology were valued differently by professionals and students. Hence, the third research question is stated as follows;

Q3: Is there any diffirence between the perceptions of accounting students and professionals in terms of the significance level of accounting skills?

\section{DATA AND METHODOLOGY}

The aim of this study is to identify the skills that should be gained in accounting education according to the perceptions of students and the expectations of professional accountants. In the study, it was also tried to determine whether there is a difference between the opinions of the students and the practitioners about the related skills.

Since the skills covered in the study should be gained to the students during the accounting education process, it is a necessity that students take part in the research scope. In addition, it is important that the opinions of the professional accountants involved in the practice take part in the study. Therefore, the scope of the research was composed of both students and professionals.

Survey method was used as a data collection tool in the research. The questionnaire was developed by Kearns (2014). However, the skills included in the survey, were revised in the framework of accounting education in Turkey. So that were adapted into existing curricula.

The survey consists of two parts. The first section contains demographic questions, and the second section lists 30 accounting skills. Accounting skills in the second part are divided into three groups according to the classification of AICPA. Respondents were asked to evaluate these skills with the help of the 5-point Likert scale: 1: not important at all, 2: important, 3: undecided, 4: important, 5: very important.

The questionnaire was applied to 224 randomly selected students in the departments of business, international trade and business administration, accounting and tax and business management of the School of Political Sciences, School of Applied 
Sciences and Vocational School of Social Sciences at Çanakkale Onsekiz Mart University. Besides, 47 professional members registered to Çanakkale Chamber of Certified Public Accountant were included in the survey.

The data obtained were analyzed in SPSS 20 package program. The average and standard deviation for each of the accounting skills included in the questionnaire were calculated, and the significance of the accounting skills was determined. In addition, it was investigated whether there is a difference between the opinions of students and professional accountants. Since the data did not show a normal distribution, Mann-Whitney $U$ Test, which measures the difference between two independent groups, was applied. The reliability of the questionnaire was measured by Cronbach's alpha coefficient. The cronbach alpha value of the questionnaire was 0.927 .

\section{FINDINGS}

In this section, general information about the students and professionals in the study and the analysis results of the opinions of students and professionals about accounting skills are given.

\subsection{General Information of Students and Professionals}

The results of frequency analysis of students and accounting professionals participated in the survey are given in Table 1 and Table 2 below.

Table 1: Frequency Data of Students

\begin{tabular}{llcc}
\hline & & Frequency & Percentage \\
\hline Gender & Female & 114 & 50,9 \\
\hline & Male & 110 & 49,1 \\
\hline State of Education & Associate degree & $\mathbf{1 0 1}$ & $\mathbf{4 5 , 1}$ \\
\hline & College & 52 & 23,2 \\
\hline & Undergraduate & 71 & 31,7 \\
\hline Job Status & Not working & 159 & 71 \\
\hline & Part-time work & 47 & 21 \\
\hline & Working & 18 & 8 \\
\hline
\end{tabular}

Table 1 presents the frequencies and percentages of the students in terms of gender, education and job status. The majority of the students who participated in the research were female with $50.9 \%$ and associate students with $45.1 \%$. These data show that the majority of students do not work with $71 \%$.

Table 2: Frequency Data of Accounting Professionals

\begin{tabular}{llcc}
\hline & & Frequency & Percentage \\
\hline Gender & Female & 33 & 70,2 \\
\hline Professional Title & Male & 14 & 29,8 \\
& $\begin{array}{l}\text { Independent Accountant and } \\
\text { Financial Advisor }\end{array}$ & 28 & 59,6 \\
\hline & Certified Public Accountant & 1 & 2,1 \\
\hline & Accounting Personnel & 18 & 38,3 \\
\hline Occupational Experience & $1-4$ Year & 11 & 23,4 \\
\hline & $5-10$ Year & 14 & 29,8 \\
\hline & $11-15$ Year & 8 & 17 \\
\hline & $16-20$ year & 5 & 10,6 \\
\hline & More than 20 year & 9 & 19,1 \\
\hline
\end{tabular}

Table 2 presents the frequencies and percentages of the accounting professionals in terms of gender, professional title and occupational experience. The majority of the professional accountants participated in the study were male with $70.2 \%$ and independent accountants with 59. $6 \%$. These data show that $29.8 \%$ of the members of the profession have an occupational experience of between $5-10$ years.

\subsection{Perception of Importance of Skills for Students and Professionals}

The 30 skills to be gained in accounting education were asked to students and accounting professionals in order to determine about importance. The mean and standard deviation were calculated according to the answers of both groups and the significance levels of these skills were determined. The results of these are given in Table 3. 
Table 3: Skills to be Gained in Accounting Education According to Students and Professional Accountants

\begin{tabular}{|c|c|c|c|c|c|c|}
\hline \multirow[t]{2}{*}{ Skills } & \multicolumn{3}{|c|}{$\begin{array}{c}\text { Students } \\
\text { (224 persons) }\end{array}$} & \multicolumn{3}{|c|}{$\begin{array}{l}\text { Accounting Professionals } \\
\text { (47 persons) }\end{array}$} \\
\hline & Mean & Rank & Std.Dev. & Mean & Rank & Std.Dev. \\
\hline Ethical Behavior & 4,21 & 8 & ,96 & 4,51 & 5 & 59 \\
\hline Communication Skills & 4,34 & 1 & ,75 & 4,49 & 7 & ,59 \\
\hline Critical and Analytical Thinking & 4,18 & 9 & ,88 & 4,30 & 13 & ,66 \\
\hline Problem Solving & 4,29 & 2 & 80 & 4,38 & 11 & 74 \\
\hline Team Working & 3,88 & 25 & 1,10 & 4,47 & 8 & 69 \\
\hline Social Skills & 3,79 & 27 & ,94 & 4,23 & 19 & 60 \\
\hline Preparation of Financial Statement & 4,02 & 16 & 1,02 & 4,70 & 1 & ,62 \\
\hline Financial Statement Analysis & 3,96 & 20 & 1,04 & 4,62 & 2 & ,64 \\
\hline Deviation Analysis & 3,62 & 30 & ,99 & 4,04 & 29 & ,78 \\
\hline Budget and Analysis & 3,94 & 22 & 1,01 & 4,28 & 15 & 77 \\
\hline Internal Control & 3,67 & 29 & 1,04 & 4,45 & 9 & ,75 \\
\hline Risk Management & 3,96 & 21 & ,98 & 4,21 & 21 & ,62 \\
\hline Activity-Based Costing & 3,86 & 26 & 1,03 & 4,17 & 23 & ,79 \\
\hline Phase and Order Costing & 3,91 & 23 & 1,00 & 4,15 & 25 & ,72 \\
\hline Stock Management & 4,06 & 13 & ,94 & 4,28 & 14 & ,97 \\
\hline Detection and Prevention of Fraud & 4,22 & 6 & 1,06 & 4,57 & 3 &, 54 \\
\hline Financial Forecast & 4,10 & 11 & ,84 & 4,23 & 20 & 63 \\
\hline Cost-Volume-Profit Analysis & 4,26 & 3 & 87 & 4,23 & 18 & ,73 \\
\hline Present Value & 3,98 & 20 & ,90 & 4,15 & 24 & 62 \\
\hline Auditing Stds Evidence Collection & 3,71 & 28 & 1,01 & 4,15 & 26 &, 59 \\
\hline Fixed Assets and Depreciation Accounting & 3,99 & 17 & ,97 & 4,26 & 17 &, 53 \\
\hline Business Law & 4,04 & 15 & 1,05 & 4,40 & 10 &, 54 \\
\hline Basic Tax Applications & 4,22 & 5 & ,94 & 4,49 & 6 &, 51 \\
\hline Audit Report Preparation & 3,99 & 19 & ,94 & 4,28 & 16 & ,85 \\
\hline Foreign Currency Transfer & 4,05 & 14 & ,99 & 3,57 & 30 & ,93 \\
\hline Current Package Programs & 3,89 & 24 & 1,04 & 4,17 & 22 & 87 \\
\hline Excel Spreadsheets in Accounting & 4,21 & 7 & ,91 & 4,34 & 12 & 79 \\
\hline Database Tools & 4,12 & 10 & 87 & 4,04 & 28 & ,78 \\
\hline Information Technology Security & 4,06 & 12 & ,97 & 4,51 & 4 &, 55 \\
\hline Accounting Information System Designing & 4,23 & 4 & ,95 & 4,11 & 27 & 89 \\
\hline
\end{tabular}

As seen in Table 3, according to students, the first five skills that should be gained in accounting education are as follows; communication skills, problem solving, cost-volume-profit analysis, accounting information system designing and basic tax applications. The students in the scope of this study, ranked the first two general skills (Communication skills and problem solving skill) as the most important skills. The students might have given importance to these skills on the grounds that they would need them during the recruitment process and in their future career.

Accounting education is mostly given in business administration and business management departments and the importance of making profit and profitability for the enterprises in the education process of the students in these departments, is constantly emphasized. Therefore, the students may have stated "Cost-Volume-Profit Analysis" used as a profit planning tool in the third place. On the other hand, it is seen that the degree of importance given to "cost-volume-profit analysis" and "accounting information system designing" skills by the professionals is low.

Similarly, in the accounting education process, it is emphasized that the most important element of the business information system is the accounting information system in terms of carrying out the activities of the enterprises. This may have caused students to consider "accounting information system designing" as the 4th most important skill to acquire. On the other hand, it is seen that the degree of importance given to "cost-volume-profit analysis" and "accounting information system designing in skills by the professionals is low.

Since the accounting process is tax-oriented in practice, students stated that basic tax applications are important for accounting education. Although "basic tax practice" is not among the top five skills according to the accounting professions, it is also important for them. They rank "basic tax practices" in the 6th place.

Professional accountants in the study stated that basic accounting knowledge and functional skills should be acquired primarily in accounting education as seen in Table 3 . In this context, according to professionals, the first two most important skills are preparation and analysis of financial statements. In contrast to professionals, the degree of importance that students attach to "financial report preparation" and "financial analysis" skills is much lower. 
Another important functional skill for professionals is "detection and prevention of fraud". It is expected that accounting audit will be important for professional accountants. According to the students, "detection and prevention of fraud" is in the 6 th position even though it is not in the top five. This finding shows students' awareness of the importance of accounting auditing in the accounting education process.

Widespread use of information technology in the field of accounting leads to the realization of many accounting transactions electronically. This situation has made the concept of information technology security important for the activities carried out in the accounting process. In this context, professional accountants within the scope of the study evaluated the importance of "information technology security" as well as gaining knowledge and skills related to information technologies in accounting education.

Since the accounting profession is not only a profession requiring technical expertise, it is very important that professionals have ethical and social responsibility awareness. In particular, the responsibility placed on the accounting profession has increased nowadays and accountants are expected to have professional qualification and to be impartial, independent decision makers and honest professionals. In this context, the professional members of the study stated that ethical behavior is one of the most important skills to be gained in accounting education.

\subsection{Differences of Opinions between Students and Professionals}

The Mann-Whitney $U$ test was used to analyze the differences between the opinions of students and professional accountants about the skills required in accounting education. The analysis results are given in Table 4.

Table 4: Differences Between Students and Professional Accountants

\begin{tabular}{|c|c|c|c|c|}
\hline Skills & $\begin{array}{c}\text { Mann- } \\
\text { Whitney U }\end{array}$ & $\begin{array}{c}\text { Wilcoxon } \\
\text { W }\end{array}$ & $\mathbf{z}$ & $\begin{array}{l}\text { Asymp. Sig. } \\
\text { (2-tailed) }\end{array}$ \\
\hline Ethical Behavior & 5187,000 & 6315,000 &,- 173 & 862 \\
\hline Communication Skills & 5125,500 & 30325,500 &,- 313 & ,754 \\
\hline Critical and Analytical Thinking & 4319,500 & 29519,500 & $-2,097$ & 036 \\
\hline Problem Solving & 4754,500 & 5882,500 & $-1,151$ & ,250 \\
\hline Team Working & 2778,500 & 27978,500 & $-5,396$ & 000 \\
\hline Social Skills & 2531,000 & 27731,000 & $-5,916$ & 000 \\
\hline Preparation of Financial Statement & 5097,500 & 6225,500 &,- 360 & ,719 \\
\hline Financial Statement Analysis & 4502,000 & 29702,000 & $-1,649$ & 099 \\
\hline Deviation Analysis & 2765,000 & 27965,000 & $-5,348$ & 000 \\
\hline Budget and Analysis & 4690,500 & 29890,500 & $-1,250$ & 211 \\
\hline Internal Control & 3824,500 & 29024,500 & $-3,086$ & 002 \\
\hline Risk Management & 4840,000 & 30040,000 &,- 921 & 357 \\
\hline Activity-Based Costing & 3965,500 & 29165,500 & $-2,795$ & 005 \\
\hline Phase and Order Costing & 3235,000 & 28435,000 & $-4,426$ & 000 \\
\hline Stock Management & 4944,000 & 30144,000 &,- 705 & ,481 \\
\hline Detection and Prevention of Fraud & 4819,000 & 5947,000 &,- 997 & ,319 \\
\hline Financial Forecast & 5264,000 & 6392,000 & 000 & 1,000 \\
\hline Cost-Volume-Profit Analysis & 4493,500 & 5621,500 & $-1,708$ & 088 \\
\hline Present Value & 4483,000 & 29683,000 & $-1,703$ & 088 \\
\hline Auditing Stds Evidence Collection & 3184,500 & 28384,500 & $-4,537$ & 000 \\
\hline Fixed Assets and Depreciation Acctg. & 3881,000 & 29081,000 & $-3,005$ & 003 \\
\hline Business Law & 4717,000 & 29917,000 & $-1,197$ &, 231 \\
\hline Basic Tax Applications & 3139,000 & 4267,000 & $-4,644$ & 000 \\
\hline Audit Report Preparation & 4720,500 & 29920,500 & $-1,180$ & ,238 \\
\hline Foreign Currency Transfer & 4496,000 & 29696,000 & $-1,675$ & 094 \\
\hline Current Package Programs & 4965,500 & 30165,500 &,- 647 &, 518 \\
\hline Excel Spreadsheets in Accounting & 4503,500 & 29703,500 & $-1,695$ & 090 \\
\hline Database Tools & 5253,500 & 30453,500 &,- 023 & 982 \\
\hline Information Technology Security & 4015,500 & 29215,500 & $-2,730$ & 006 \\
\hline Acctg. Information System Designing & 4719,000 & 5847,000 & $-1,208$ & ,227 \\
\hline
\end{tabular}

As a result of the research, it was found that there were differences between the opinions of students and professional accountants in 11 out of 30 skills that should be included in accounting education. These skills are; critical and analytical thinking, team working, social skills, deviation analysis, internal control, activity-based costing, phase and order costing, auditing stds evidence collection, fixed assets and depreciation accounting, basic tax applications and information technology security. When the findings was examined, it was seen that professional accountants gave more importance to all skills that 
had differences between the opinions of students and professionals. Apart from these skills, there is no difference between the opinions of students and professionals for other skills in the table.

\section{DISCUSSIONS AND CONCLUSION}

In the study, three research questions were tested. Firstly, the significance level of accounting skills perceived by students was investigated. Research findings show that the most important skills to be gained in accounting education according to students are "communication" and "problem solving" similar to the results of Gabric and Mc Fadden (2001). Moreover, as the students listed four of the six general skills as top ten, they considered the general skills which are important for employability and long lasting success, were more important in accounting education. The students in the study emphasized that information technology skills are also important for accounting education. They evaluated three of the five information technology skills in the top ten. On the other hand, students ranked only three of the nineteen functional skills that are specific to acountancy, in the top ten and eight in the top twenty.

Secondly, the significance level of accounting skills perceived by professional accountants was investigated in the study. The results of the research are similar to those of Paratama (2015). According to professionals, the most important skills to be gained in accounting education are "financial accounting" and "reporting". Although the professionals stated that the two most important skills to be acquired in accounting education are functional skills as "financial reporting" and "financial analysis", they evaluated only six of the nineteen functional skills in the top ten. Professionals also stated that general skills are important, like students, by grading three out of six general skills in the top ten. But, professionals evaluated only "information technology security" skill of five information technology skills included in the study, in the top ten.

Finally, it was investigated whether there is a difference between the perceptions of accounting students and professionals about the importance of accounting skills. When the rankings of accounting experts and accounting students were compared, it was found that professionals and students had different opinions about 11 accounting skills. According to the findings of the study, as Kavanag and Drennan (2008) had revealed, there was a parallelism between the opinions of students and professionals in terms of skills required for a successful career in todays' business life such as communication, problem solving, ethical behavior skills. Furthermore, students gave more importance to lifelong learning skills, while professionals gave more importance to professional knowledge and skills.

Finally, although there are similarities between students' perceptions and expectations of professionals in terms of skills to be gained in accounting education, there are some differences. Therefore, it would be appropriate to review and update the accounting education in line with the expectations considering these differences. It is also possible to make arrangements in the course contents in order to gain the skills that the professionals concerned about.

There are two limitations in the study. First, the study was conducted only in Çanakkale. Another limitation of the study is that the professional accountants working in the enterprises were not been included in the study and only those who were registered to Çanakkale Chamber of Certified Public Accountant were included in the study. However, there is no significant difference in accounting education and accounting curriculum at the universities, results obtained in the study will contribute to the assessment of the accounting education in Turkey.

\section{REFERENCES}

Albrecht, W. Steve and Sack, Robert J. (2000). Accounting Education: Charting the Course Through a Perilous Future, Sarasota, FL: The American Accounting Association.

Ali, Inalia Mohd, Kamarudin, Khairunnisak, Suriani, Nur Adila, Saad, Nur Zulaikha and Afandi, Zati Arifah M. (2016). Perception of Employers and Educators in Accounting Education, Procedia Economics and Finance, 35, 54- 63.

Asonitou, Sofia. (2015). "The Evolution of Accounting Education and the Development of Skills", 11th Interdisciplinary Workshop On Intangibles, Intellectual Capital and Extra-Financial Information, Athens University of Economics and Business, 17 September 2015.

Awayiga, Joseph Y., Onumah, Joseph M. and Tsamenyi, Mathew. (2010). Knowledge and Skills Development of Accounting Graduates: The Perceptions of Graduates and Employers in Ghana, Accounting education: an International Journal, Vol. 19, Nos. 1- 2, February- April 2010, 139- 158.

Arsoy, Aylin Poroy, Bora, Tuba and Selimoğlu, Seval. (2014). Muhasebe Eğitimindeki Bilgi, Beceri ve Eğitim Tekniklerinin Gerekliliklerine İlişkin Beklentiler: Türkiye'deki Akademisyenlere ve Meslek Mensuplarına Yönelik Bir Araştırma, International Journal of Management Economics and Business, Vol. 10, No. 23, 121- 136.

Chaker, Mohammed Naim and Abdullah, Tengku Akbar. (2011). What Accountancy Skills are Acquired at College?, International Journal of Business and Social Science, Vol. 2, No. 18, October 2011, 193- 199.

Çürük, Turgut ve Doğan, Zeki.(2001). Muhasebe Eğitiminin İşletmelerin Taleplerini Karşılama Düzeyi: Türkiye Örneği, ODTÜ Gelişme Dergisi, 28 (3- 4), 281- 310.

Dağdeviren, İbrahim Ethem, Mirza, Şakir ve Dağdeviren, Fatma. (2016) . Muhasebe Programının Öğrenci Perspektifinden Değerlendirilmesine Yönelik Uşak Üniversitesinde Bir Araştırma, Uluslararası Yönetim iktisat ve Işletme Dergisi, ICARF 16 Özel Sayısı, $491-505$. 
Francisco, Bill and Kelly, Ann. (2002). Beyong Albrecht and Sack: A Comparison of Accounting Professionals and College Students, American Institute of Certified Public Accountants.

Gabric, Daniela and McFadden, Kathleen L. (2001). Student and Employer Perceptions of Desirable Entry-Level Operations Management Skills, Mid- American Journal of Business, Volume 16, Number 1, Spring 2001, 51- 59.

Gökçen, Gürbüz. (1998). Uygulamacıların Muhasebe Eğitiminden Beklentileri, Muhasebe Finansman Dergisi, T.C. Marmara Üniversitesi Muhasebe Araştırma Merkezi, Y. 7, S. 9, 43- 50.

Greenstein, Marilyn and McKee, Thomas E. (2004). Assurance Practitioners and Educators Self-Perceived IT Knowledge Level: An Empirical Assessment, International Journal of Accounting Information Systems, 5, 213- 243.

Ingram, Robert W. and Albright, Thomas L. (2007). Financial Accounting, USA: South-Western Cengage Learning.

Jackling, Beverley and De Lange, Paul. (2009). Do Accounting Graduates Skills Meet The Expectations of Employers? A Matter of Convergence or Divergence, Accounting Education: An International Journal, Vol. 18, Nos.4 -5, September- December 2009, $369-385$.

Kalmiş Halis ve Yilmaz Berna B. (2004). Lisans Seviyesindeki Muhasebe Eğitiminin Mevcut Durumu Ve Geliştirilmesi İçin Yapılması Gereken Geliştirmeler, XXIII. Türkiye Muhasebe Eğitimi Sempozyumu, 19- 23 Mayıs 2004, Antalya, 1- 15, 2004.

Kavanagh, Marie H. and Drennan, Lyndal. (2008) What Skills and Attributes Does an Accounting Graduate need? Evidence from Students Perceptions and Employers Expectations, Accounting and Finance, 48, 249- 300.

Kearns, Grover S. (2014). The Importance of Accounting Information Systems in the Accounting Curricula: A CPA Perspective, AIS Educator Journal, Volume 9, Number 1, 24- 40.

Kendirli, Selçuk, Ülker, Yakup ve Yamaltdinova, Adilya. (2015). Accounting Education at Faculty of Economic Administrative Science in Kyrgyzstan Universities and Expectation of Students from Accounting Education, A Case Study in Bishkek, Research Journal of Business and Management, Volume: 2, Issue: 1, 52- 68

Klibi, Mohamed Faker and Oussii, Ahmed Atef. (2013). Skills and Attributes Needed for Success in Accounting Career: Do Employers' Expectations Fit with Students' Perceptions? Evidence from Tunisia, International Journal of Business and Management, Vol. 8, No. 8, 118132.

Lin, Z. Jun, Xiong, Xiaoyan and Lui, Min. (2005). Knowledge Base and Skill Development in Accounting Education: Evidence from China, Journal of Accounting Education, 23, 149- 169.

Mohamed, Ehab K.A. ve Lashine, Sherif H. (2003). Accounting Knowledge and Skills and the Challenges of A Global Business Enviroment, Managerial Finance, Volume 29, Number 7, 3- 16.

Özdemir, Serkan ve Elitaş, Cemal. (2015). Ön Lisans Muhasebe ve Vergi Bölümü Öğrencilerine Verilen Mesleki Eğitime Genel Bir Bakış: Ege Bölgesi'nde Bir Uygulama, XXXIV. Türkiye Muhasebe Eğitimi Sempozyumu, Mayıs Antalya, 21- 36, 2015.

Paratama, Arie. (2015). Bringing The Gap Between Academicians and Practitioners on Accountant Competencies: An Analysis of International Education Standards (IES) Implementation on Indonesia's Accounting Education, Procedia Social and Behavioral Science, $211,19-26$.

Sin, Samantha and Reid Anna. (2005). Developing Generic Skills in Accounting: Resourcing and Reflecting on Trans-Disciplinary Research and Insights, Australian Association for Research in Education, Conference, 1- 22.

Stumke, Olive. (2017). Information Technology in Accoutancy Curricula: Necessity or Afterthought, International Journal of Business and Government Studies, Vol 9, No 2, 121- 135

Sürmeli, Fevzi. (2007). Muhasebe Eğitiminde e-Değişimi Yakalamak, Muhasebe ve Finans Dergisi, Sayı 33, Ocak 2007, 28- 30.

Tan, Lin Mei and Fawzi, Laswad. (2017). Employability Skills Required of Accountants, SHS Web of Conference 34, 06001.

Tan, Lin Mei, Fowler, Michael B. and Hawkes, Lindsay. (2004). Management Accounting Curricula: Striking a Balance Between The Views of Educators and Practitioners, Accounting Education, 13 (1), 51- 67.

Uyar, Ali and Güngörmüş, Ali Haydar. (2011). Professional Knowledge and Skills Required for Accounting Majors Who Intend to Become Auditors: Perceptions of External Auditors, Business and Economics Research Journal, Volume 2, Number 3, 33- 49.

Zaif, Figen ve Ayanoğlu, Yıldız. (2007). Muhasebe Eğitiminde Kalitenin Arttırılmasında Ders Programlarının Önemi: Türkiye'de Bir İnceleme, Gazi Üniversitesi İktisadi ve Idari Bilimler Fakültesi Dergisi, 9/ 1, 115- 136. 